\title{
Vepsa rahvaluule lummas
}

\author{
$\underline{\text { Kristi Salve }}$
}

MinuVepsa-harrastusel on eellugu, mille tahangi sissejuhatuseks jutustada.

Olin ehk 9-10-aastane ja juba suur raamatusõber, kui mu lugemislauale sattus mahukas kogumik paljude tolleaegse Nõukogude Liidu piires elavate rahvaste muinasjuttudest. Suurest enamusest raamatus esindatud rahvastest polnud ma enne kuulnud, aga ainult kahe nimed "Vepsa muinasjutt" ja "Mari muinasjutt" - erutasid mu

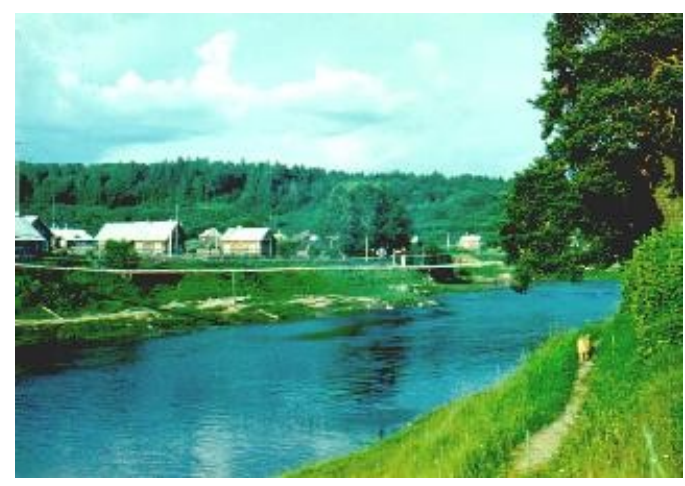
kujutlusvõimet ja jäid korrapealt igaveseks meelde. Viimasel juhul on põhjuski kergelt arvatav - see on kokkulangevus eestlastel populaarse naisenimega Mari. Niisiis võis mõelda Mari muinasjutust ja selle kõrval Jüri omast. Aga Vepsa? Selle taga võisid peituda kõige salapärasemad asjad, mida ma püüdsin asjata mõistatada. See nimi ei lasknud enam lahti.

Aeg läks ja kui keskkooli lõpus käies hakkasin huvi tundma filoloogia vastu, siis sain teada, et vepslased on meie, eestlaste, lähedased keelesugulased. Ülikooliõpingud andsid juba konkreetsemaid teadmisi vepsa keelest - keeleajaloo kursusest jäi meelde rida näiteid selle vanapärasusest, nagu astmevahelduse puudumine (nimetav kääne lambaz, omastav lambhan, olevikuvormid nagu andab jpt), ja konkreetsemaks muutus ka minu huvi. Midagi otsustavamat ma selle rahuldamiseks siiski ette ei võtnud.

Oli möödunud mõni aasta ülikooli lõpetamisest ja ma töötasin pärast Võrumaad ja Tallinnat juba Tartus, tollases Kirjandusmuuseumi rahvaluuleosakonnas, endises ja praeguses Eesti Rahvaluule Arhiivis, kui Eesti Rahva Muuseumis korraldati Vepsa-teemaline õhtu. Räägiti selle rahva keelest ja kultuurist, näidati diapositiive ja esemeid, ansambel "Hellero" laulis mõned rahvalaulud. Mõistsin äkki, et mu ülikooli üldkursustest ammendatud teadmised on väga väikesed ning et ma tahan neid suurendada. Pealegi sööbisid mu mällu arheoloog Tanel Moora sõnad: "See maa on ilus... See maa on väga ilus. Me peame oma Pühajärve mingiks imeks, mida kaugelt vaatama sõidetakse. Seal on kümneid selliseid järvi."

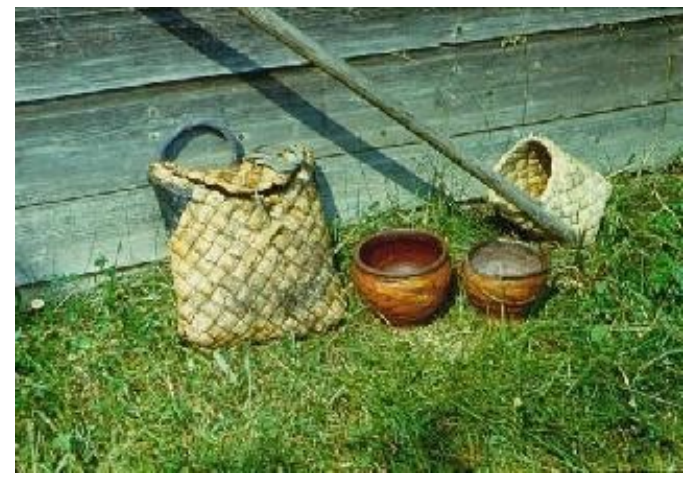

Lähemail päevil rääkisingi Marje Joalaiuga, kes oli vepslaste juures käima hakanud juba üliõpilasena, ning leppisime kokku, et järgmisel suvel sõidan temaga kaasa. 1973. a. kevadsuvel - sõitsime välja mai lõpul, ning Vepsamaa metsade all oli veel üksikuid lumelaike - saigi teoks mu esimene Vepsa-matk. 
Esimesele lisandus teine, kolmas, neljas. Tekkis harjumus, ja see süvenes lausa paratamatuseks. Või mis see siis on, kui ma hakkan kevadeti nägema unenägusid, milles ma kõnnin Vepsamaa radasid, istun taredes ja vestlen inimestega, kuulen ja räägin vepsa keelt! Niisugused unenäod tähendavad minu jaoks seda, et tuleb hakata ennast teekonnaks valmistama.

Kaks esimest matka viisid mind Lõuna-Vepsa murdeala küladesse, kuhu kolmandat korda sattusin alles mitmeteistkümne aasta pärast. Ühe korra olen käinud Põhja- ehk Äänis-Vepsas, samuti korra Vologda oblastis idapoolseimate vepslaste juures. Mu põhiliseks paigaks on aga saanud ja jäänud Kesk-Vepsa Ojati jõe piirkond. Sealsed külad on mulle kõik tuttavad,enamikus neist olen viibinud korduvalt, nii näiteks Järvedes, Ladvas, Vilhalas. Kaardilt, teeviitadelt ja trükiste enamikust

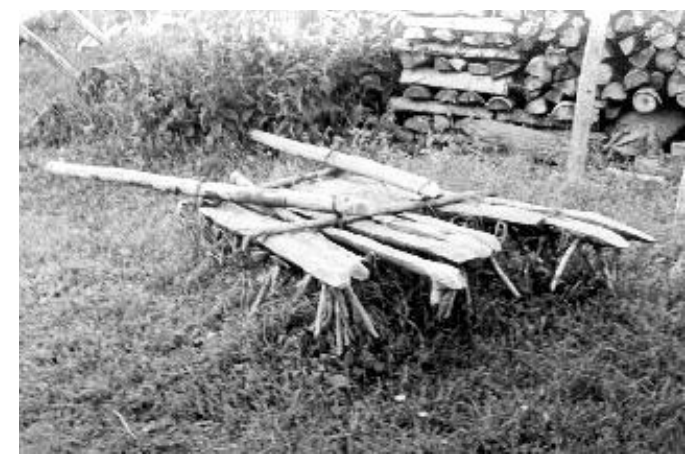
(välja arvatud vepsa keelematerjalide kogumikud ning viimastel aastatel ilmunud ajaleht "Kodima") selliseid nimesid ei leia. Ametlikult käibivad üksnes venekeelsed kohanimed, mis on saadud kas vepsa keelest tõlkimise (Järved > Ozjora) või häälikulise mugandamise teel. Vahel on nimetatud võimalusi kombineeritud (Mägjärvest on saanud Mjagozero), aga mõnel juhul on seost kahe nime vahel üldse raske tabada (Vilhal $>$ Jaroslavitshi).

Olen folklorist ja sellepärast, kuigi mu Vepsa-mälestustes on tähtis koht kaunil loodusel, kuigi meenutan tänulikult paljusid lahkeid inimesi, kes on mind lugematuid kordi kostitanud tee ja teekõrvasega ning pakkunud öömaja ja kuigi tunnen jatkuvat rõõmu arhailise, pehmekõlalise vepsa keele kuulamisest, on mu jaoks kõige olulisem siiski vepsa rahvaluule kogumine. See on olnud rõõmuks ja rahulduseks ennekõike mulle endale, kuid loodan sedakaudu anda midagi rikastavat ka oma rahvale, vepslastele enestele ja kui nüüd õige suureliseks minna, siis kogu maailmale. Just see usk on julgustanud mind koputama ustele, segada inimesi tööde-talituste juures, olla oma küsimustega võib-olla tüütugi.

Ma pole oma kogumistööd kuidagi zhanriliselt piiranud, vaid olen üles kirjutanud ja lindistanud nii laule kui jutte, nii itke kui kombestikukirjeldusi, nii vanasõnu kui mõistatusi. Muidugi olen meie folkloristide eelnevate põlvkondade Eestis kujunenud tava järgides arvestanud iga küsitletava kalduvusi ja suurema rõhu pannud neile rahvaluuleliikidele, milles kellelgi on paistnud suuremad teadmised olevat. Mõni teab hulgakaupa uuemaid rahvalaule, milleks vepslastel on nelikvärsid e tshastushkad (vepsa keeles nimetatakse neid enamasti lihtsalt pajod, st laulud), aga teine võib-olla üheainsa, kuid seda huvitavama, vormilt runolaululähedase hällilaulu. Üks räägib väga ilmekalt loomamuinasjutte, kujutades tõelise näitlejameisterlikkusega mitut liiki loomade karaktereid (tõeline proovikivi on selles suhtes "Itkejate otsimine" (AT 37*), teine jälle väidab - ja küllap õigusega - , et ta muinasjutte üldse ei oska, kuid suurepärane jutustaja on temagi. Ilmneb, et ta võib lõpmatult rääkida tõestisündinuiks peetud lugusid metshaldjatest, nendega suhtlevatest nõidadest, täitunud ennustuslikest unenägudest, koju käivaist surnutest ja muust üleloomulikust. Vanasõnu saab edukalt küsida ainult väheste, eriti taibukate ning kriitilise meelega inimeste käest. Seda varasemate folkloristide järeldust on kinnitanud $\mathrm{ka} m u$ enese kogemused. Erandiks on kalendrivanasõnad, mida saab peaaegu igaühe käest päris hästi küsida tähtpäeva järgi - märksõnaks on sel juhul päeva nimetus. Seevastu enamiku vanasõnade puhul ei andnud tulemusi neis iseloomustatud olukorra konkreetne ja otsesõnaline kirjeldamine. Suunavale küsimusele Kut 
sanoiba nened encced ristitud, konz naprimer mam hubin radoi, i tütar mugazho? ('kuidas need endised inimesed ütlesid, kui näiteks ema tegi halvasti ja tütar samuti?') võis hõlpsalt järgneda seda pisut muudetud sõnastuses kordav vastus: Muga $i$ sanoiba : mam huba oli i tütar möst. ('nii ütlesidki: ema oli halb ja tütar ka'). - Sobivad vanasõnad, mida ma tahtsin välja meelitada, oleksid olnud näiteks: Mite kandoine, mugo $i$ vezoine ('kuidas kännuke, nii ka võsuke') või Käbu kuzespää edhaks ii lankte ('käbi ei kuku kuusest kaugele'). Vepsa vanasõnadest mõeldes meenub mulle esimesena Zina Volkova, Vilhala Reboimäel asuva väikese kaupluse müüja. Sinna tulnud ostjad ei kiirustanud lahkumisega, vaid arutasid Zinaga ja üksteisega külaelu ja suure maailma sündmusi ning neist juttudest võis kirjapanemiseks noppida mõnegi vanasõna ja kõnekäänu. Zina enese ilmekasse kõnesse põimusid vanasõnad ja kõnekäänud alatihti, kuid ta oli ka üks neist vähestest, kes oli valmis ja võimeline neid eriliselt minu jaoks meenutama.

Kuigi igasuguste hierarhiate tegemine on kahtlane ettevõte, võib vist siiski öelda, et vepsa rahvaluule kesksemad liigid on itkud ja muinasjutud ning neist on saanud ka minu erilise huvi objektid. Muinasjutud liigina olid mind köitnud küll juba enne minu esimesi Vepsa-matkasid, kuid köitnud eeskätt kui fikseeritud tekstid, lõpetatud ja muutumatud. Ma olin vaimustatud põnevatest süzheedest, tihti lausa rabavatest detailidest, aga ka võimalusest avastada muinasjuttude kaudu muistseid usundilisi kujutelmi ja rahvastevahelisi kultuurikontakte. Elava esituse võludega puutusin ulatuslikumalt kokku alles Vepsamaal, kuigi olin ju varem kohanud Kagu-Eestis, eriti muidugi Setumaal häid muinasjutuvestjaid ja nende esitusi lindistanud. On siiski tõsiasi, et need kokkupuuted setu jutustajategagi said minu jaoks õige tähenduse ja kõlajõu alles Vepsa-muljete taustal. Just Vepsamaal kogesin, kui oluline on muinasjutu teksti kõrval kontekst, mõistsin muinasjutu kui erilise kommunikatsioonivormi tähendust. Eriti tänuväärsed on olnud niisugused jutustamissituatsioonid, kus peale jutustaja ja minu osales ka vepslastest kuulajaid. Enamasti ongi lindistamise juures viibinud kas teisi pereliikmeid või mõni naaber, kelle siirast kaasaelamist olen saanud jälgida. Mõnel sellisel puhul võisin kogeda, kuidas hinnati muinasjututegelaste käitumist nagu reaalsete isikute oma. Kui ema käsib hukata oma vastsündinud lapse, kuna see on juba looteeas tema käitumist tauninud (AT 920), kui mõlemad vanemad langetavad otsuse lapsed kaugele metsa viia ja seal eksitada (AT 327), siis olen kuulnud sügava nördimusega öeldavat: Micced ristitud! ('missugused inimesed!') Vahel esitab ka jutustaja ise vahemärkusi, mis tema meelest aitavad lugu paremini mõista. sest mine sa kuulajate taibukust tea, eriti kui on tegemist noortega või minusuguse kaugelt tulnuga. Niisugused selgitused, näiteks endisaegsesse elu-olusse või jälle üleloomulikkuse sfääri puutuvad, esitatakse nii-öelda "sulgudes" ja nad eristuvad jutu põhiosast intonatsiooni poolest, vahel õigegi teravalt.

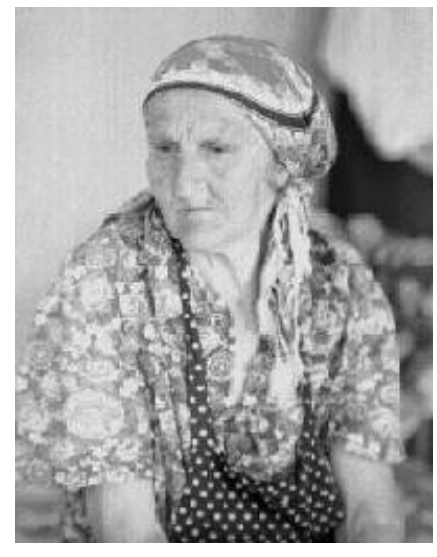

Kuigi mul on meenutada paljusid häid jutustajaid paljudest küladest, tuleb siiski tõe huvides hoiatada: ärgu keegi arvaku, et vepsa muinasjutt elab tänapäeval üle mingit õitsenguperioodi. Otse vastupidi - tegemist on ikkagi kaduva kultuurinähtusega. See taandumisprotsess on olnud selgesti tajutav ka nende mõneteistkümne aasta jooksul, mil mina olen Vepsa radadel rännanud. 1970. aastail kohtasin ma tunduvalt rohkem häid jutustajaid kui 1980., üheksakümnendaiks on need üpris haruldaseks muutunud.

Need vepslased, kel eluaastaid praeguseks üle 70 , st kes on sündinud kahekümnendate aastate alguses või keskpaikugi, on veel suures osas 
muinasjuttude peal üles kasvanud. Üsna üldiselt meenutatakse talveõhtuid, kui lapsed olid roninud ahju peale muinasjutte rääkiva vanaisa-vanaemaga. Kui aga oma perest jutustajat ei leidunud, siis koguneti mõne selles suhtes võimeka naabri juurde. Siiski on ainult vähesed neist lapsepõlves muinasjutte kuulanuist võimelised tänapäeval ise jutustama. Jutustamistraditsiooni katkemise põhjusi on mitu: vahepealsed üldiselt rasked ajalooperioodid, uute meelelahutusvormide (kino, televisioon) levik, aga ka keelelise järjepidevuse katkemine viimastel aegadel: vepsa muinasjutte oskavatel vanaemadelgi pole sageli olnud võimalik neid oma lapselastele jutustada, kuna need elavad suurelt jaolt linnades, ei oska enamasti vepsa keeltki, võib-olla ei huvita neid muinasjutud, kui vanaemad oleksidki suutelised käigu pealt tõlkima, mis mõnegi jaoks on jälle liiga raske. Muidugi on niisuguste üldiste suundumuste kõrvale võimalik tuua ka üksikuid vastupidiseid näiteid veel viimaseist aastakümneist, kus vanaemad on jutustanud lastelastele või üksi elav eideke talveõhtuil eakaaslastele. Ja nii või teisiti, kas tänu eriti heale mälule või "treeningule" aktiivse traditsioonikandjana, aga igal juhul võib Vepsas tänini kohata jutustajaid, kes mitte ainult ei anna edasi enamasti põnevat sündmustikku, vaid kes esitavad mitmest küljest imetletava kunstiteose. Väljapaistva jutustaja oma laad algab juba repertuaari valikust, aga sinna kuulub ka isikupärane sõnastusstiil ja esitusviis.

Üks mulle kõige tugevamat muljet avaldanuist oli Vassoi-tädi, pime jutustaja Vassilissa Jeroshkina Sondjalast. Tänaseks on ta juba ammu Mana maile lahkunud. Tema jutustajameisterlikkuse seisukohalt polnud kindlasti tähenduseta ta füüsiline puuegi, mida ta küll aastakümnete jooksul oli argielus paljuski ületama õppinud, saades iseseisvalt hakkama suurema osaga kodustest toimetustest. Aga sunnitud jõudeolekut on pimedal paratamatult rohkesti ja aja täitmiseks on juttude-laulude meenutamine parim vahend. Nii polegi ime, et eepilise traditsiooni heade tundjate hulgas on erinevate rahvaste juures leidunud pimedaid, alates juba poolmüütilisest Homerosest. Vassilissa Jeroshkina eelistatud muinasjututegelaseks oli ülekohtu tõttu kannatav tütarlaps või noorik, nagu see esineb muinasjuttudes "Kätetu" (AT 706), "Võõrasema ja vaeslaps" (AT 480 versioonid), "Imepärased lapsed" (AT 707) ja mitmed muud. Kuigi jutud süütult kannatavast kangelannast olid Vassoi-tädile küllap väga isiklikel põhjustel kõige lähedasemad, oli ta repertuaaris ka hoopis erinevas tonaalsuses lugusid, nagu näiteks muinasjutud meistervargast ja lolli tempudest. Vassoi-tädi jutustas rahulikult, pikkamisi langesid sõnad, aeglaselt reastusid laused. Traditsioonist kinni pidades esitas ta kõik korduvad episoodid kolm või rohkem korda suure mõnuga täpselt samas sõnastuses. Eelnevale vasturääkiv oli ta kohatine püüd jutu sisu detailides kaasajastada - näiteks tsaaripoeg kihutab ühes jutus koju kiirrongiga, teisel puhul on juttu sööklast vms.

Marfa Mikshina, Ladva jutustaja, kes oli päritolult küll mägjälleine ('mägjärvelane'), oli oma laadilt täiesti erinev. Tumedasilmse, kehalt kuivetu ja meelelaadilt kärsitu Marfa esitus oli temperamentne, sõnad veeresid nagu herned rabinal ja jutt edenes kiiresti. Näis, et ta oli isegi vahel üllatatud ootamatuist käänakuist muinasjutukangelaste saatuses. Suhteliselt sagedamini võis tema juttudes kohata arhailisi motiive, olustik ja kõnepruuk olid karmimad ja jämedamad. Kui mõnel tegelasel oli vaja kas ajutiselt eemalduda või soovis ta päriselt põgeneda, siis oli ettekääne alati üks: Kuzi lähteb.

Tüseda keha ja optimistliku meelelaadiga Matrjona Pavlova Enjärvest rääkis muhedalt ja lahedalt kõiki jutte, oli nende sisu siis milline tahes, haledust tekitav või hirmutav, põnev või naljakas. Aleksandra Karpova Järvedest on jälle aastate tagant elavalt meelde jäänud sellepärast, et ta jutus ette tulevatele koomilistele situatsioonidele elas ise kaasa lausa ohjeldamatu naeruga. Oli isegi raske 
uskuda tagantjärele kuuldud lugusid temast kui tunnustatud nõiast, nii lihtsameelse mulje oli ta suutnud endast jätta. Onoi (Anisja) Markova Mägjärvest oli iseloomult lahke ja leebe, aga ta meisterlikult esitatud muinasjuttudes oli iga sõna täpselt ja rangeltki õigesse paika pandud - nagu ka kõik asjad ta väga korralikus majapidamises.

Esimestena meenuvad jutustajad olid niisiis kõik naised ja seda täiesti põhjendatult. Suurema repertuaariga ja meisterlikumad minu kohatud muinasjutuvestjaist on tõepoolest olnud eakad naised. Ka põhiosa kõigist enda kogutud muinasjuttudest olen saanud neilt. Oleks aga vale sellest midagi järeldada vepsa muinasjututraditsiooni üldise olemuse või selle varasemate perioodide kohta. Põhjused on väga lihtsad ja täiesti folkloorivälised: vanu mehi on vepsa külades mitu korda vähem kui naisi. Suurelt jaolt on see muidugi sõdade süü, kuid kaasa mõjub ka meeste keskmiselt lühem eluiga rahuaegadel. Minevikus olid asjad teisiti. Nagu oli tasakaalus naiste ja meeste arv, nii ka nende osatähtsus muinasjututraditsiooni hoidjana. Näib, et valitses koguni mingisugune tööjaotus. Naised, kelle hooleks nagunii olid kodu ja laste eest hoolitsemine, jutustasid rohkem lastele ja omas peres. Need jutustajad aga, keda täiskasvanud külarahvas pikkadel talvistel õhtutel hulgana kuulama tuli, olid mälestusteadete järgi enamasti mehed. Täiskasvanutest kuulajaskonnale jutustati ka välistöödel, näiteks kaugetel heinamaadel, kus ööbiti, või siis samuti kaugetel raielankidel.Vastavalt esitajate ja kuulajate eale ja soole erinesid ka repertuaarid. On huvitav, et päris mitmes külas on mineviku heade muinasjutuvestjatena nimetatud karjaseid. Samasuguseid teateid on ju Eestistki.

Mul pole enam olnud õnne kohata ülistatud jutustajaid, kelle repertuaarid olevat olnud lausa ammendamatud, nii et nad olevat võinud kuulajaile pakkuda õhtust õhtusse üha uusi jutte. Suhteliselt väheste meesjutustajate hulgast, keda olen lindistanud, meenub oma aja kohta kaunis suure repertuaariga Semoi Tshernjakov Pecoilast, kelle sundimatu esituslaad ja sõnavalitsemise oskus lasksid aimata, et soodsamal juhul oleks temast võinud tõeline meister kujuneda. Mulle on jutustanud veel mõnedki vanataadid, kelle juures oli kõige elamuslikum nende välimus: vabalt kasvanud hallid juuksed ja habe tõid selgelt silma ette vepslaste tänapäevani aktuaalse metshaldja, mecizhanda. Aga kaks mulle kõige suurema rõõmuelamuse valmistanud juttu on jutustanud tublisti nooremad, meie kohtumiste ajal umbes viiekümneaastased mehed, kes kumbki teadiski ainult selle ühe - aga see-eest missuguse! - jutu.Vilhala töömees jutustas näljases sõjaaegses lapsepõlves vanaemalt kuuldud imemuinasjutu. See oli juba süzheelt keerukas, arvukate kõrvalepisoodidega, korduvate pingetõusude ja -langustega enne lõpplahenduseni jõudmist. Korduvalt pidin vahetama magnetofonilinte ja lõpuks sundis põnevus lausa hinge kinni pidama: kui kaua see rekordjutt õieti kesta võib? Ja see arvatavasti kõige pikem vepsa muinasjutt, mis kunagi fikseeritud, oli ka selles mõttes huvitav, et sarnanes rohkem ühele eesti sama tüübi variandile kui mulle teadaolevatele vene ja karjala omadele.

Teine jutt, mille kuulsin Ladvas ja mis kutsus esile lausa folkloristliku vapustuse, on rohkem ajalooline pärimus kui muinasjutt. Minu jutustajale oli seda tõestisündinud loona rääkinud tema isa, kes pidi ometi olema igapidi usaldatav. Kõnealune jutt on vene uurijate poolt ammu tähelepanemist leidnud. Selle oluliseks põhjuseks on ta seos bõliinaga "Rahta Ragnozerski," sest bõliinad on ju vene folkloori lugupeetuim zhanr. Tähelepandavamaid viimase aja käsitlusi pärineb K. Tshistovi sulest, kes sidus jutu algpäritolu saamide või vene kroonikas mainitud vessidega (nii nimetati ilmselt tänapäeva vepslaste esivanemaid). Vepslastelt polnud selleks ajaks siiski ainsatki teisendit teada ja see oli ka üheks põhjuseks, miks J. Smirnov oma samale jutule pühendatud uurimuses K. 
Tshistovi seisukoha kahtluse alla pani. Minus oli see jutt, mis kinnitab naise ja tütre reetlikkust ning poja ustavust, huvi äratanud selle tõttu, et teadsin ta tuntud olevat Siberi põlisrahvastel. Ja nüüd kuulsin seda jutustavat vepslast, kes oskas isegi sündmuspaiga kaunis täpselt ära määrata. Rääkis noorepoolne, igas suhtes ärksa mõtlemisega mees, aga see kõlas nagu hääl igavikust, sest selle jutu kindlasti mitme tuhande aastani ulatuva vanuse kõrval on inimese eluaastad tõesti tühine suurus.

Meelde on jäänud ka paar lapsjutustajat 1970. aastaist. Nende jutud olid küll kohapeal improviseeritud või kordasid äsja täiskasvanu esituses kuuldut, aga nad ise kibelesid mikrofoni rääkima. Magnetofon oli siis vepsa külas veel vägagi uus ja põnev asi. Kahjuks pole ma viimastel aastatel enam kohanud selliseid lapsi, kes oleksid suutnud ja tahtnud emakeeles jutustada. Toredaks ja vepsa keele kestmise suhtes julgust andvaks kogemuseks oli siiski see, et 1995. aastal õnnestus mu kaaslastel lindistada lastelt ehtsat traditsiooni esindavaid muinasjutte Pondlas, mis kuulub idapoolsemate vepsa külade hulka. Ma ise sain aga mõne aasta eest ühelt Järvede koolitüdrukult lindistada paar vepsakeelset laulukest. Võib-olla oli selle tüdruku huvi oma rahvaluule vastu äratanud esimene nn "Vepsa pidu", mitmepäevane kultuuriüritus folkloorikontsertide, näituste ja konverentsiga, mis toimus 1987. a. suvel ja ulatus otsapidi ka Järvedesse.

Eespool oli juttu sellest, et Vepsamaa andis mulle elava jutustamise kogemuse. Kuigi sellised jutustamissituatsioonid, millest kõneldakse mälestusteadetes, pole mulle enam kättesaadavad olnud, on siiski väga sageli, kui mitte enamasti, peale minu enese lindistamise ajal ka teisi kuulajaid, olgu siis oma pere liikmete või naabrite näol. Olen saanud jälgida siirast kaasaelamist ning kuulata kommentaare, mis hindavad jututegelaste käitumist või arutlusi, kas nii- või teistsugused sündmused on võinud tõesti aset leida. Vahel esitab ka jutustaja ise vahemärkusi, mis tema meelest on vajalikud paremaks mõistmiseks, sest mine sa kuulajate taibukust tea, eriti kui on tegemist noortega või kaugelt tulnuga nagu mina. Niisugused märkused esitatakse niiöelda "sulgudes" ja nad eristuvad jutu põhiosast intonatsiooni poolest, vahel õige teravalt.

Vepsa rahvaluule laululistest zhanritest on kahtlemata kõige omapärasemad, rikkamad ja esinduslikumad itkud. Erinevalt muinasjuttudest elab vähemalt itkude kõige tähtsam ja küllap ka kõige vanem alaliik - surnuitk - tänini. Nagu kauges minevikus kõlavad itkud ka tänapäeval matustel ja mälestuspäevadel ning mõned lindistusedki olen saanud teha otse tavandilises kontekstis. Valdav enamik mu ligikaudu veerandtuhandest itkulindistusest on siiski spetsiaalselt minu palvel mikrofoni ees esitatud itkud. Neist omakorda on märgatav osa pühendatud ammu - või koguni väga ammu - kaotatud lähiomastele - emale, isale, sõjas langenud mehele. Sellistel juhtudel võib sageli täheldada rituaalitku tunnuste vähenemist ja ähmastumist, samal ajal kui itkeja enda elusaatusest kõnelevate motiivide osatähtsus aina kasvab. Lõpptulemus võib juba olla pigem tavandiväline autobiograafiline itk, kuigi mõte on hargnema hakanud ikka lähedase surnu meenutamisest.

Praegune vepsa naiste vanem põlvkond on elanud kõike muud kui kerget elu, nii et itkemiseks on põhjust küllaga. Paljud neist kasvasid orbudena - isad olid langenud I maailmasõjas - ning juba varases nooruses pidid nad võtma enda peale raske töökoorma. Noorte tütarlastena on paljud osalenud kohustuslikel metsatöödel, mis ju

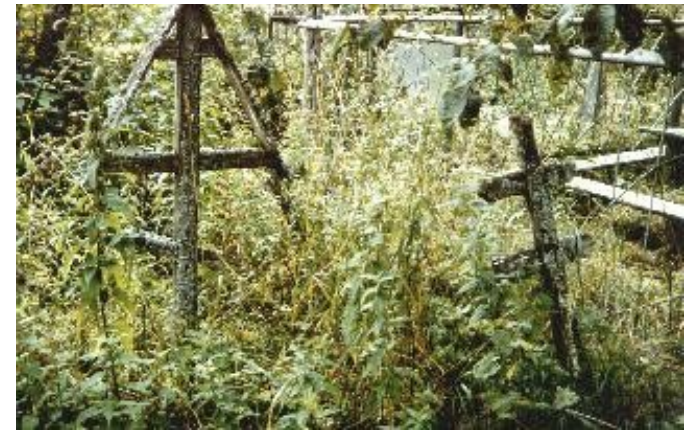


naistele õigupoolest üldse jõukohased pole. Kui noore inimese tervis vastu pidas, siis võis vabal ajal rõõmuski olla, laulda ja tantsida. Aga edasi läks veel raskemaks. Kolmekümnendate aastate lõpupoole abiellunud ja emaks saanud vepsa noorikute tavaline saatus oli mehe kaotus sõdades ja lesepõlv. Millist vaeva nähti laste üleskasvatamisega sõjaaegsetel ja -järgsetel näljaaegadel! Vaevaga jäädi enneaegu vanaks, aga vanaduski pole muretu. Pensionid on viimase ajani olnud liiga väikesed, aga aiamaa ülesharimiseks ja küttepuude muretsemiseks on raha ometi vaja. Enamasti ollakse vanaduspäevil üksi, sest suure surmaga üles kasvatatud lapsed on siirdunud mujale paremat elu otsima. Aga vähe sellest, et lastest pole loodetud tuge - emasüda muretseb veel nende käekäigu pärast, eriti kui pikemat aega pole teateid vahel väga ja väga kaugel elavatelt poegadelt ja tütardelt. Olen kuulnud lugusid Kasahstani ja Kaug-Itta kadunutest, kellelt emad pole rohkem kui kümne aasta jooksul kirja saanud. Kas nad pole ehk enam üldse elavate kirjaski? Või kas nad on tõesti võinud nii kalgisüdamelised olla ja ema unustada? Need mõtted võtavad itku vormi nii mõnel tuhmil sügisõhtul üksi oma tares istudes kui ka rahvaluulekoguja mikrofoni ees. Jah, minu kohatud Kesk-Vepsa itkejate kohta võib küll kõhklemata öelda, et elu ise on nad itkema õpetanud olgu siis lähedaste kaotuse või igapäevamurede koorma kandmise kaudu.

Neil surnuvalvamistel, matustel ja mälestuspäevadel, kus ma olen viibinud, on leinatavateksitketavateks juhtunud olema eakad inimesed ja kuigi itkejate - õdede, sugulaste, naabrite - lein oli kahtlemata siiras, leevendas seda teadmine, et lahkunu jõudis läbida kõik inimesele ettenähtud eluetapid ja et leinajad isegi jõuavad peatselt sama piiripostini. Minevikumeenutused lahkunuga koos läbielatud aegadest, temalt saadud abist ja kogetud südameheadusest, nagu need itkudes tavalised on, kutsuvad esile eelkõige heldimuspisaraid. Itkejalt kanduvad need ka pealtkuulajale ja tulemuseks on, et silmavesi uhub ära surmaga kokkupuutumisest paratamatult tuleneva ängi ning süda saab jälle kergemaks.

Kui püüda kõige lühemini iseloomustada itkude funktsiooni, siis võib öelda, et nad on sügava tarkusega loodud abivahend leinatunnete, lahkumisvalu, tulevikuhirmu ja muu säärase kanaliseerimiseks ja seega ületamiseks. Itkud on suurepärane näide tõelise kultuuri kõikehõlmavusest. Tänapäeva euroopalikul inimesel, kelle jaoks kultuur tähendab eeskätt vaba aja sisustamise vahendit, on ilmselt raske mõista, et on olemas ka leinamiskultuur - põlvest põlve edasi antud ja iga uue põlvkonna poolt õpitud käitumisviisid pere, suguvõsa, kogukonna liikme surma puhul.

Seda, millist vaimset tuge ja psühhoteraapiat kujutab endast itk, saab kõige selgemini näha selliste itkejate-itketavate suhte juures, mis on vastuolus loodusseadustega ja mida inimlik mõistus keeldub vastuvõetavaks tunnistamast. Kuidas peab ema ära saatma igaveseks lahkunud lapsi - või vanaema lapselast? Valu on niisugusel puhul liiga suur, inimene osutub selle ees võimetuks, ta hing võib murduda või laguneda. Itk toob oma pärimuslikkuses appi esivanemate kogemuse. Isiklik valu voolab varasemate põlvkondade kannatuste mõõtmatusse merre. Itk paneb äsjalahkunuga suhtlemiseks suhu osalt vanad ja valmis sõnad, mille ümber saab koondada ka oma ainukordseid mälestusi ja tundeid väljendavaid värsiridu. Itk aitab maha laadida elu ja tervist ohustavat liigpinget.

Lauri Honko on itkejate kohta öelnud, et nad on lovesse langevate shamaanide emad ja õed. Nende sõnadega on tabatud midagi väga olulist. Võib-olla oleks tänapäeval, kus shamanism on läänemeresoomlastel minevikku jäänud, küll veidi sobivam öelda, et nad on shamaanide tütred ja tütretütred. Itk on tõepoolest shamanistlikult ekstaatiline ja itk ületab samuti Toonela piirid nagu seda teeb ka oma rahva jaoks tervist ja toitu otsiv shamaan. 
Ilmselt tuleneb see esmapilgul uskumatu tõsiasi, et inimesed on üldse nõus rahvaluulekogujale itkema, just itku pingeid maandavast ja niisiis teraapilisest mõjust. Kui just küla peal pole talle enne jõutud kõnelda, siis ei ole kaugelt tulnud folklorist teadlik kellegi lähimineviku valusatest kaotustest ja võib itke küsides lihtsalt kogemata kinnikasvamata haava osatada. Mis oleks lihtsam, kui et ta minema saata, eitades oma itkemisoskust. Võimalik, et mõnikord on sellist taktikat minu suhtes rakendatudki, ja ma ei imestaks selle üle, solvumisest rääkimata. Imestama panevad pigem need arvukad juhtumid, kus mulle on vastatud: "Hea küll, ma itken sulle nii, nagu ma itkesin möödunud suvel oma pojale (või....sügisel oma õele ... või kevadel oma tütrepojale..). Enamasti olen seejärel võinud märgata, kuidas mina ja magnetofon, õieti kogu muu maailm ununeb juba esimeste itkuvärsside järel. Südamel lasuv mure mahutatakse esmalt sellesse pärimuslikku sõnalismuusikalisse teosesse, mida nimetame itkuks, aga mõne minuti möödudes osutuvad needki traditsiooniraamid liig kitsaiks ja silmist purskuvad pisarad, mis uhuvad minema kõik ettejääva. Tuleb tunnistada, et esimesed kokkupuuted ülima tundejõuga esitatud vepsa itkudega mõjusid mulle ehmatavalt. Minu jahmatuses polnud midagi erandlikku, sest teisest kultuurist tulnud on ehedat itku ennegi võõristanud, olgu siis näiteks E.Lönnroti Karjala-kogemus või saksa reisija J.A. v. Brandi muljed Kagu-Eesti itkust.

Itkemine kulgeb tavaliselt nii, et nuuksed juba esimeste ridade lõpus asenduvad natukese aja pärast tõeliste nutupausidega, mis muutuvad pikemaks ja hakkavad mõjutama kogu järgmist rida, pisarad voolavad lõpuks juba ojadena, itkeja ei jõua enam sõnu seada ja viisi pidada ning siis kostabki ainult pidurdamatu nutt, nuuksed, oiged ja ürgkarjed. Nii alasti, vähemalgi määral varjamata valu oli võorristav näha. Pealegi tundsin hirmu, et enamasti kõrges eas itkejad võivad enda tervisele rängasti häda teha. See pole olnud ainult minu kartus. Olen korduvalt näinud, kuidas matustel, värskel haual ja mälestuspäevadel on teised matuselised või mälestajad itkejaid isegi katkestanud ja neid jõuga (õlast raputades, kalmule kummardanut jalule tõstes jne) püüdnud siinpoolsusse tagasi tuua. Niisiis tekkis kõhklus, kas mul on õigust paluda itkemist.

See kõhkluseperiood ei kestnud kaua. Hakkasin nimelt tähele panema, et mingil moel - kasvõi alateadlikult - pidid need reeglina palju muresid läbi elanud vepsa naised ise itkeda tahtma. Miks nad siis muidu enamasti soostusid mu ettepanekuga - või miks hakkas mõni itkema üsna omal algatusel, kui jutt oli läinud mõnele lähiminevikus kaotatud kallile omaksele. Pidi olema kergendav mõne aja tagant oma lein itkus ja selle kaudu vallapäästetud nutus nö maha laadida. Niisugusele arusaamisele jõudnuna rahunesin ega kartnud enam, et itkude kogumisega halba teen.

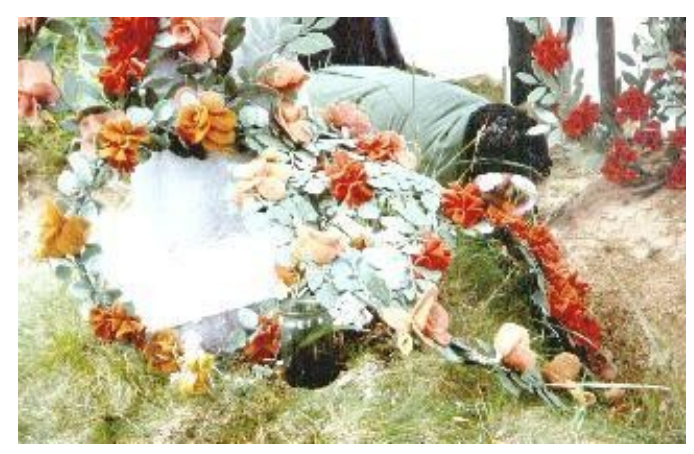

Nagu paljudest muinasjuttude jutustajatest, nii ka itkejatest on jäänud mälestusi, mida möödunud aastate hulk pole suutnud kustutada. Kõrvus kajab ikka veel esimene kuuldud ehe itk. See oli 1973. aastal LõunaVepsas Peloila kalmistul, kus Sodjärve külast pärit noor naine itkes oma õe haual kõrgel, kiljuval häälel. Oskasin tol korral veel väga vähe vepsa keelt, kuid raske oleks sellest olnud sõnu eristada ka suurema keeletundmise korral. Iidne kõla oli see, mis mind vapustas - ja selle kontrast itkeja seljas oleva tollal nii moodsa krimpleenkostüümiga. 
Ajapikku selgus, et nende kõrval, kes nö itkevad välja iseenda valu, leidub ka kogukonna poolt üldiselt tunnustatud meistreid, kes valdavad kogu traditsioonilist sõnade, viisi ja esituse varamut ning kellelt seetõttu on eeldatud itkemist ka sellistele surnutele, kes pole talle kuigi lähedalt või isegi üldse mitte sugulane, vaid näiteks lihtsalt sama küla inimene ja seega vähemalt tuttav. Mulle paistab, nagu tunneksid niisugused esiletõusvad anded ka ise kohustust itkeda, eriti niisugustel juhtudel, kui keegi kadunuga lähedasemas suhtes olevatest surnuvalvamisel, matuse ajal või mälestuspäeval laua taga itku ei alusta. Siiani peetakse itkemist normikohaseks ja see tähendab ühtlasi, et oskajal ei sobi küünalt vaka all hoida.

Üks selliseid meisterlikke itkejaid oli Maria Joroshkova Sondjalast, muide eespool nimetatud Vassoi vennanaine. Ta oli vepslase kohta üpris pikakasvuline ja eakanagi laskis korrapäraste joontega nägu aimata, kui ilus tüdruk ta kunagi oli olnud. Kui ta mõndagi (näiteks nõiatarkust) oli õppinud pimedalt naolt, siis itkeda oli ta juba mehele minnes hästi osanud. Kas need pikad pulmaitkud kunagi aastakümnete eest just neid sõnu sisaldasid, nagu nad said lindile jäädvustatud, on muidugi küsitav, aga põhilised sisumotiivid ja kunstivõtete varamu on vaieldamatult samad.

Sama küla elanik Nastoi Trifonova oli üks neid, keda külarahvas ütles itkevat "omadele ja võõrastele". Ta jättiski esimestel kohtumisel väga tugeva mulje. Sellal oli Nastoi Trifonova veel täies tervises ja

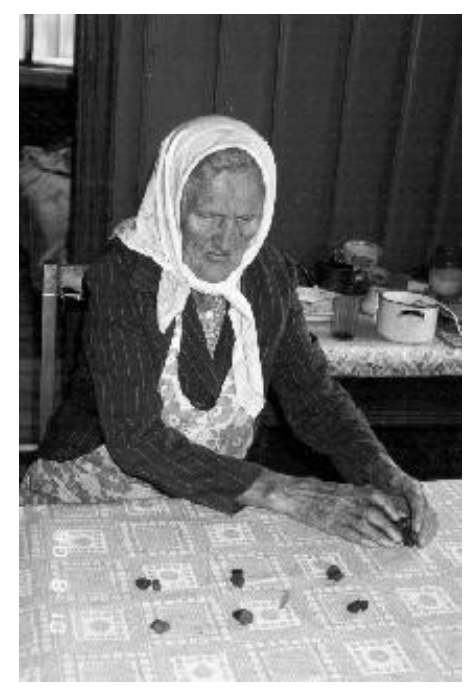
elujõus. Ta hääl oli kume ja kandev. Erinevalt vepsa itkejate tavalisest jäägitust kaasaelamisest, millega olin juba harjunud, näis tema suutvat itku sisust mõnevõrra distantseeruda. Ta mõjus parimas mõttes professionaalina. Kui kümnekonna aasta pärast jälle Shondjalasse ja Nastoi juurde jõudsin, võisin tõdeda, et vahepealsed aastad olid viinud mitte ainult tervise, jõu ja nendega otseselt seotud hääle, vaid ka vaimujõu, millega ta varem kõik juuresviibijad oma mõjule allutas.

Kui muinasjutte ja itke võib tõepoolest pidada vepsa rahvaluule kõige esinduslikumateks liikideks, siis pole imestada, kui eredamad mälestused seostuvadki valdavalt jutustajate-itkejatega. Aga siiski on erandeid. Eespool oli näiteks juttu Vilhala poemüüjast Zina Volkovast. Meelde on jäänud ka teisi inimesi, kel on olnud kujundlik keelepruuk, kes on kasutanud oma jutus ja suutnud ka küsimise peale täiendavalt meenutada vanasõnu-kõnekäände. Maria Abramova Ladvast võib jutustada ilmekalt ja kuulamasundivalt argistestki asjadest, aga ta teab ka muinasjutte ja laule, viimaste seas ka tõelisi haruldusi, nagu näiteks ürgvana jutustav laul taevastest kosilastest - meie "Salme laulu" vaste. Pole ime, et andekal emal on andekas poeg - Nikolai Abramov on nimelt esimese vepsakeelse luuletuskogu autor.

Meelest ei lähe tagasihoidliku olemisega Ladva külastu järvetaguses osas elanud Aleksandra Prohhorova, kellelt võisin lindistada vepsa rahvaluules väga haruldase legendilaulu, mis jutustas jumalainimesest Aleksiusest. Ja veel rida mitmetel eri viisidel unustamatuid inimesi, keda ühendab see, et nad on ladlized ladvalased. Ladvast on teistes piirkonna külades arvamus, et seal just osataksa laule ja muinasjutte, et just seal elavad tõelised vepslased. Tõsi küll, oma kõrvalisema asendi tõttu ehk ongi ta üht teist paremini säilitanud, aga naaberkülade kõrgendatud arvamus põhines suuresti sellel, et Ladva naiste lauludest oli välja lastud heliplaat. Sellega täiesti võrreldavat 
nähtust olen kodumaal kogenud - kui juhtumisi mõni Muhu või Setu laulik või Võrumaa pillimees oli esinenud raadios, siis kümne kilomeetri raadiuses ei tahtnud keegi muu enam rahvaluulekogujat jutule võtta, vaid soovitasid tüütuseni ikka sedasama kohalikku kuulsust.

Oksju Gerassimova oskas muinasjutte, laule ja itke, aga kõige rohkem on kohtumistestest temaga meelde jäänud ta jutud enda elust ja üks isiklikult mulle määratud lause. Mishakovide peres oli hea pärimusetundja ämm, aga mõnevõrra ootamatumalt oskas miniagi toredaid muinasjutte rääkida, ning omad ja naabrilapsed olid tänuväärseks publikuks.

Võiks veel nimetada paljusid, kes on meelde jäänud nime ja nägu pidi, aga on teistsuguseid inimesi, neid, kellest tunnistavad üksikud või arvukadki laulud, jutud, itkud, vanasõnad, mõistatused, uskumused ja materiaalse kultuuri kohta käivad andmed arhiivis, kuid kellest mulle midagi isiklikumat aastate tagant ei meenu. Ja vastupidistki on: inimesi, keda ma mäletan, kuid kellest pole midagi arhiivi jõudnud. Kõikidel on aga oma osa terviku kujunemisel. Mälestuste võluvaip koosneb värvikaist koelõngadest ja lõimest, mis välja ei paista, aga mille osa on just kudet koos hoida.

Ükskõik kui pikalt ma oma Vepsa-mälestusi veel jätkaksin, ikka jõuaksin ainult väikese osa jutustada. Olgu siis juba siinkohal lõpetatud. Ainult paar märkust tuleb veel teha. Esiteks on mu muljed kindlasti olnud mõjutatud tõsiasjast, et olen vepsa külades käinud rahvaluulekogujana, ja siinses kirjatöös olen veel eriti keskendunud pärimusele ja pärimusekandjatele. Nii võibki jääda üpris idülliline, ehk pastelse nukrusega kergelt toonitatud pilt. See on õige, kuid muidugi ühekülgne. Küllaga on tumedat ja süngetki, samuti lootusetult halli ja porikarvalist. Vepsa elu mõnedest muudest aspektidest, samuti mõnedest pärimusliikidest olen aga püüdnud teavet anda mujal, siin seda korrata poleks mõtet.

Lõpetan - nagu alustasingi- lapsepõlvemeenutusega. Umbes sama aja paiku, kui sain teada vepslaste olemasolust, sattusin ajalehest lugema Paul Ariste kirjutist soome-ugri keeltest ja nende uurimisest, eriti Eestis. Otsustasin siis, et kunagi hakkan ka mina õppima soome-ugri keeli. Aastate pärast lõpetasin ülikooli lõpetasin küll folkloristina, aga hiljem olen oma lapsepõlvekavatsuse juurde kaudselt tagasi jõudnud. Paul Ariste mõju? Küllap sedagi võiks hea tahtmise korral leida, kuigi ju nii lihtsad põhjuse-tagajärje suhted maailmas ka ei valitse. Aga üks on kindel - selle lugemise pealkiri on kõnealuse kuulsa kaasmaalase ühe artikli pealkirja variant.

Kaik/kõik; selle sõnaga lõpevad paljud vepsa laulude-juttude lindistused/. 